\title{
THE GINSBURGS COLLECTION: SOVIET LEGAL MATERIAL AT THE RUTGERS- CAMDEN LAW LIBRARY
}

\author{
$B Y$ LUCY COX
}

Ms. Cox is Soviet Collection Librarian at the Law Library, Rutgers-Camden

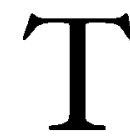

HE GINSBURGS Collection, one of the most comprehensive collections of Soviet legal and related material in the United States, is located at the Rutgers University Law School library at Camden. It consists of some 30,000 treatises and over I 50 titles of serial literature. While most of the material is postWorld War II, much earlier material available on microfiche. In scope, the collection encompasses official material, scholarly treatises and journals, as well as popular books, pamphlets, and magazines. Besides legal material, the collection also includes publications in the areas of history, political science, sociology and economics. Although the greater part of the collection deals with the Soviet Union, there is extensive coverage of the other socialist countries as well. A partial list of other countries represented includes Poland, Bulgaria, East Germany and the other East European countries; China, Mongolia, Laos, North Korea, Vietnam, and Cuba. Most of the material is in Russian, but other Slavic, as well as western, and even some eastern, languages are represented.

The core of the collection was purchased by Rutgers University in 1974 from law school professor George Ginsburgs. In I 979, a one-year Title II C grant award of \$I 3 I,855 was received by the law library for the purpose of strengthening the collection and increasing its availability by cataloging the material and by making possible the acquisition of appropriate material. During the timeframe of the grant, work was begun to catalog the collection and to enter the catalog records into the Research Libraries Information Network (RLIN). The project director was Professor Arno Liivak, head librarian of the Rutgers-Camden Law School Library. The work begun during the grant is being continued as newly-published as well as retrospective material is being purchased, catalogued, and entered into the RLIN data-base, thus making the collection's 
holdings known to interested scholars throughout the country. In the Spring of I 984, Professor Liivak made the decision to purchase Northwestern University Law School's collection of Russian legal material, thus substantially increasing the retrospective holdings of the Ginsburgs Collection. While all the areas of the collection offer a rich and interesting array of material, it would be impossible to deal with all of them in this short paper, which will limit itself to a survey of some of the Soviet legal material contained in the Ginsburgs Collection. ${ }^{1}$

Although many early Soviet jurists believed in the Marxist principle of the withering away of state and law, the reality of course is that, more than sixty years after the Bolshevik revolution, the Soviet state and its legal system hardly seem to be on the wane. The young revolutionary regime, faced with the task of running a country, began issuing decrees from the beginning, and at the present time, Soviet leaders place an ever greater emphasis on law and the concept of "legality" in general to facilitate the functioning of a complex, industrialized, multi-ethnic state. ${ }^{2}$

Soviet law as a system is generally divided into the following "branches": constitutional law, which is often referred to as state law; administrative, financial, land, civil, criminal, labor, collective-farm, family, civil procedure, criminal procedure, and corrective-labor law. The Ginsburgs Collection contains material on all of these branches, as well as on their various sub-categories such as housing law, environmental law, educational law, copyright, etc. The legal material ranges from the most scholarly and documentary to the most elementary because it is intended for the layperson or secondary school student. Among scholarly material is that pub-

In compiling this paper, two bibliographic works were especially valuable: Jenny Brine, "Union of Soviet Socialist Republics," in Official Publications of the Soviet Union and Eastern Europe, 1945-1980: A Select, Annotated Bibliography, ed. Gregory Walker (London: Mansell Pub. Ltd., I 982), pp. 263-559; V. V. Antonov, Sovetskoe zakonodatelstvo: spravochnikputevoditel po osnovnym izdaniam (Soviet Legislation: A Reference-Guide to Basic Publications) (Moscow: Kniga, 198I). As a reference tool for Soviet law in general, the following was very useful: F.J.M. Feldbrugge, ed., Encyclopedia of Soviet Law, 2 vols. (Dobbs Ferry, N.Y.: Oceana Publications, Inc.; Leiden: A. W. Sijthoff, 1973).

"On the increased "saturation" of Soviet society by legal rules, see Stanislaw Pomorski, "The Scientific-Technical Revolution and Constitutional Development," in Soviet and East European Law and the Scientific-Technical Revolution, eds. Gordon B. Smith, Peter B. Maggs, George Ginsburgs (New York: Pergamon Press, I981), pp. i I 5-1 I6. Also John Hazard, Managing Change in the USSR: the Politico-Legal Role of the Soviet Jurist (Cambridge, London: Cambridge University Press, 1983), pp. 45-47, on the increasingly important role of law and lawyers in managing Soviet society. 


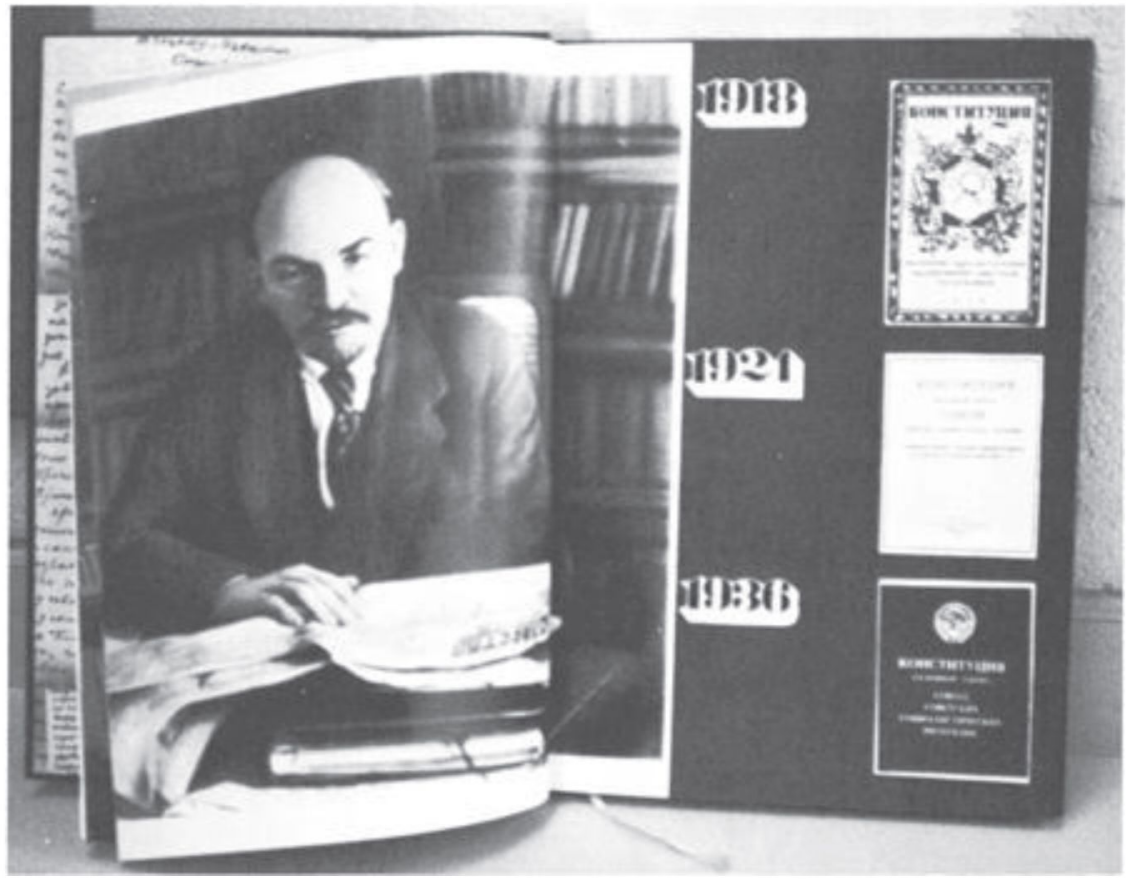

PORTRAIT OF LENIN AND THE THREE PRE-1977 SOVIET CONSTITUTIONS.

(The Ginsburgs Collection, Rutgers-Camden Law Library.)

lished under the auspices of the prestigious Institute of Law of the Academy of Sciences of the USSR, as well as by the legal institutes of the Academies of Science of the various republics. The faculties of law of the well-known Moscow and Leningrad universities, as well as of smaller institutions, are also involved in publishing. The collection includes texts for law students, official compilations of legislation and documents, bibliographies, reference books, dictionaries, encyclopedias, and treatises covering every conceivable area of law. Eminent legal authorities are represented by one or more works. There is the basic text, Soviet State Law, by A. I. Vyshinskii, Stalin's chief legal advisor and Chief Procurator of the USSR. This book deals with the 1936 constitution and is very critical of the "withering-away-of-law-school." Among important works on criminal procedure are several treatises by M. S. Stro- 
govich, the leading specialist in that field prior to the post-Stalin reforms in the late I950's. In the area of civil law and procedure there are many works by O. S. Ioffe, one of the leading authorities in that area until he was deprived of his teaching post and forced to emigrate to the U.S.A. just a few years ago. Another eminent scholar in civil law, S. N. Bratus, is also represented by several works. Other well-known scholars whose works are in the Ginsburgs Collection include A. V. Venediktov on the national economy; G. I. Tunkin on international law; L. A. Lunts on international private law; G. M. Sverdlov on family law; and N. G. Aleksandrov on labor law. D. S. Karev, who was Dean of the Faculty of Law of Moscow University and influenced post-Stalin reforms in court organization, is represented by the 1960 book, titled, in translated form, The Organization of the Court and Office of the Procurator in the USSR; Peter D. Stuchka, a leading early jurist and the first Soviet Commissar of Justice, edited the important work titled in translated form, Encyclopedia of State and Law, Moscow, I 925I 927, which contains articles by the leading scholars of that time along with copious bibliographic and statutory references.

The Constitution is considered the fundamental law [osnovnoi zakon] of the Soviet Union. The Soviet government has had four constitutions since the Revolution: the Russian Socialist Federated Republic (RSFSR) constitution of July I 9 I 8 , the first federal constitution of 1924 , the "Stalin constitution" of 1936, and the postStalin constitution of $\mathrm{I} 977$. Versions of all four of these constitutions may be found in the Ginsburgs Collection.

The first constitution, which was promulgated less than a year after the "October Revolution" of I9I7, set forth the ideals of the revolution in highly emotional language. Article 9 stated that the fundamental aim of the new regime was to establish a "dictatorship of the urban and rural proletariat and the poorest peasantry," to eliminate the bourgeoisie completely, to abolish the exploitation of "man by man," and to establish socialism, under which there would be no division into classes and no state power. It abolished private ownership of land, and deprived bourgeois elements from holding office. It included the rights of freedom of speech, press, and assembly, and the right to education. However, article 24 warned that "the RSFSR shall deprive individuals and groups of rights used to the detriment of the interests of the socialist revolution." 
Western commentators have pointed out that this article makes clear that from the very beginning of the Soviet state constitutional rights are considered privileges granted by the state to some of its citizens, subject to good behavior, rather than as inalienable rights to be protected by that state. Western commentators have also pointed out the paradox that a state which proclaims as its ideal no state power should rush to adopt a constitution so quickly after coming into power. However, they also note that the proclamation of a constitution is one of the basic measures with which a new state tries to establish its legitimacy and credentials to other states. ${ }^{3}$ The propaganda value of proclaiming an idealistic constitution was considerable, especially since the new government had forcibly dispersed the Constitutional Assembly which had been elected before the Revolution.

The 1924 constitution, the first federal constitution, was adopted after the Ukrainian, the Transcaucasian, and the Belorussian Soviet Socialist republics had joined the RSFSR to form the Soviet Union in December I 922. This constitution gave to the federal government not only the usual federal powers such as conducting foreign and military affairs, but also specifically socialist features, e.g., the development of a national economic policy.

In I 936, a second federal constitution was adopted. Stalin felt a new constitution necessary because his massive collectivization and industrialization measures had brought about a complete transformation of Soviet society since 1924. According to Stalin, "the complete victory of the socialist system in all spheres of the national economy" had been achieved, and, in the process, the "exploitation of man by man" had been eliminated.4 Many commentators have noted that the language of the 1936 Constitution is much simpler, more concise and business-like than that of the two earlier constitutions. Stalin, for the sake of efficiency, wanted the law spelled out in no uncertain terms; since he wanted everything to be controlled from the top, he could not accept the flexible approach to the interpretation of law which had been condoned under the "withering-away-of-law" philosophy. The new constitution included a greatly expanded bill of rights, and therefore seemed to promise

3 Aryeh L. Unger, Constitutional Development in the USSR: A Guide to the Soviet Constitutions (New York, Pica Press, I982), p. IO.

4 Ibid., p. 8 I. 
an age of tolerance. Instead, mass terror, the purges and political trials began shortly after the promulgation of the constitution. E. B. Pashukanis, the head of the "withering-away-of-law" school, was executed in I937. As would be the case with the I 977 constitution, the 1936 constitution was preceded by much public discussion, publicity and fanfare designed to show the democratic nature of the regime. At least one western commentator speculates that perhaps the preparation and promulgation of the constitution were meant to lull critics and camouflage preparations for the Great Purge. ${ }^{5}$ That the stress on "legality," the strict adherence to law, should develop in an atmosphere of terror is a paradox often noted. As one western scholar puts it, "in effect, terror was 'legalized.' "6 While everyone was expected to adhere to the law, the state, for purposes of political expediency, either ignored the law completely, or else interpreted it in a manner which suited its purposes.

The 1977 constitution legitimizes the anti-Stalin reforms which had begun more than twenty years ago under Khrushchev. Western commentators point to its conservative nature, its emphasis on stability and harmony. ${ }^{7}$ The Preamble stresses the maturity that the Soviet state has achieved, that it is now a "developed socialist state" which is built on the "rapprochement of all classes and social strata, of the legal and factual equality of all nations and nationalities." Some scholars have noted that this constitution, unlike the earlier ones, does not symbolize an important, dramatic "watershed" in Soviet history, but rather, consolidates the incremental improvements which Soviet society has undergone since the death of Stalin. ${ }^{8}$ It seeks to reassure that the era of terror and arbitrariness is unequivocally over. Article 4 requires that "state institutions and social organizations and officials are bound to observe the USSR constitution and Soviet laws," and Article 6 reassures that even the Communist Party, which is described in the constitution as the "leading and guiding force of Soviet society" has to operate "within the

5 Ibid., p. 83.

6 Robert Sharlet, "Stalinism and Soviet Legal Culture," in Stalinism: Essays in Historical Interpretation, ed. Robert C. Tucker (New York: Norton, I 977), p. I 65.

7 George Ginsburgs, "Dictatorship of the Proletariat versus All-People's State: Constitutional Contrasts," in Perspectives on Soviet Law for the 1980 's, ed. F.J.M. Feldbrugge and William B. Simons (The Hague; Boston: Martinus Nijhoff Pub., I982), pp. I3-14.

${ }^{8}$ George Ginsburgs and Stanislaw Pomorski, "A Profile of the Soviet Constitution of 1977," in The Constitutions of the USSR and the Union Republics: Analysis, Texts, Reports, ed. F.J.M. Feldbrugge (Alphen aan den Rijn, The Netherlands; Germantown, Md.: Sijthoff and Noordhoff, I 979), p. 7. 


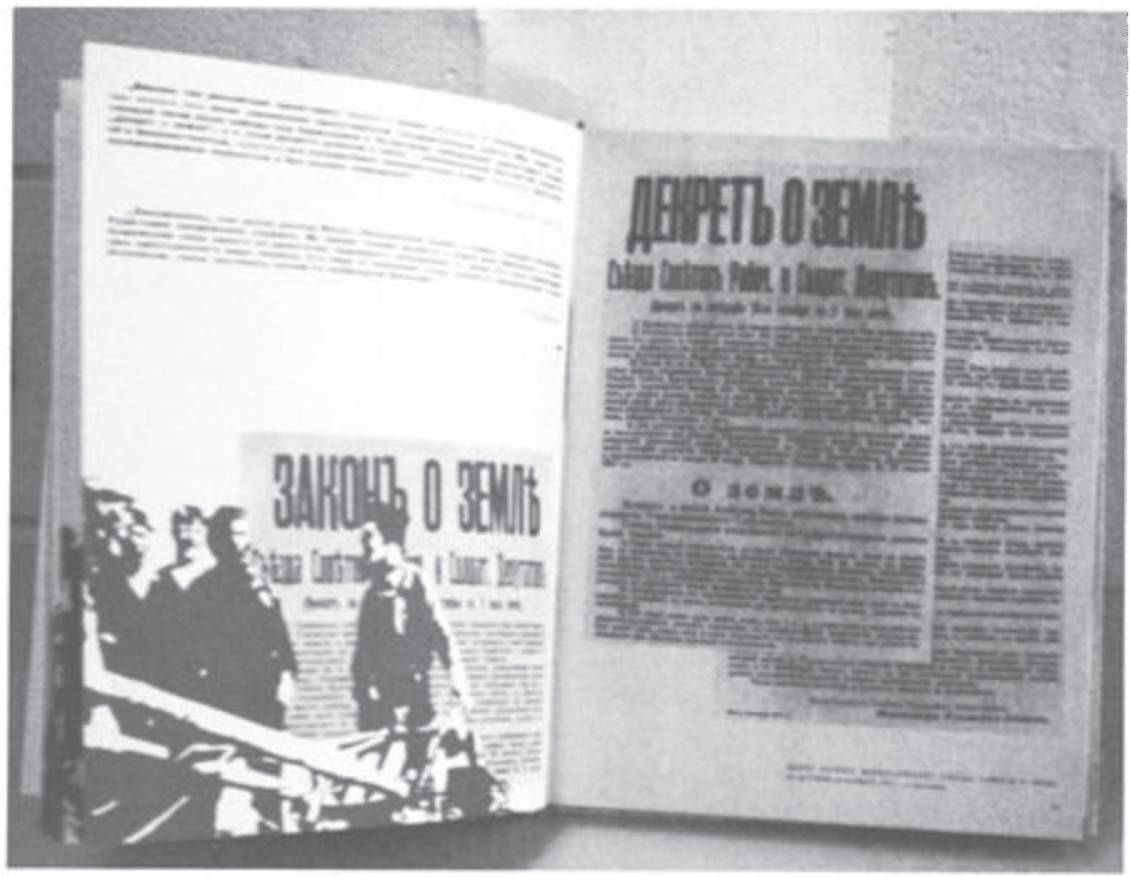

DECREE ON LAND, ONE OF THE FIRST DECREES PASSED BY THE NEW SOVIET GOVERNMENT IN 1917, ABOLISHING PRIVATE PROPERTY.

(The Ginsburgs Collection, Rutgers-Camden Law Library.)

framework of the Constitution of the USSR." The rights chapter is one of the longest in the constitution (Arts. 39-69), containing twice as many articles as the 1936 constitution. Western commentators have not failed to note, though, that social and economic rights are once more placed ahead of political rights, and that rights are conditioned on the performance of duties by citizens. ${ }^{9}$ Article 58 gives citizens the right of complaint against official abuse and arbitrariness. However, some western scholars have pointed out the lack of enabling legislation defining how article 58 should be implemented, making the constitutional guarantee "illusory." Io At least one scholar has found that the language of this constitution is

9 Gordon B. Smith, "Development of Socialist Legality," in Perspectives on Soviet Law for the 1980's, p. 93.

10 Ibid., p. 92. See also George Ginsburgs, "Dictatorship of the Proletariat," pp. 29-30, on the ambiguity involving application of Article 58. 
much worse than that of the Stalin constitution. While the I936 constitution was written in "grammatically impeccable Russian," in an austere, dignified style, the 1977 constitution is replete with grammatical errors, and in style is an "utterly inelegant mixture of bombastic rhetoric and bureaucratic jargon."

All of these constitutions, as well as documentary material dealing with the constitution, are available in the Ginsburgs Collection. The I9I8, I924, and I936 constitutions, for instance, are all included in a volume titled, in translation, The History of the Soviet Constitution. Collection of Documents, 19I7-1957 (Moscow, I957) as well as in other collections of documents and legislation. The I 977 constitution may be found as a single item issued by various publishers, as well as in general compilations of documentary material. Other compilations include not only the federal constitution, but the constitutions of the various republics.

Besides the constitutions themselves, there are many treatises dealing with constitutional law. Their titles reflect the link between the constitution and various aspects of Soviet culture. Some examples of recent titles, given in translated form, include: The USSR Constitution-Legal Basis for the Structure of Family-Spouse Relationships; The Constitutional Right to Legal Defense; The Economic Bases of the USSR Constitution. The title Actual Problems of Nationalities' Relations in the Light of the Constitution of the USSR, which is found in other variations on many other works, indicates the effort expended on the ethnic and nationalities factor by Soviet scholars. An example of the "defensive genre" of Soviet scholarship is entitled The Soviet Constitution and Myths of the Sovietologists, which decries the "myths" and "lies" of western commentators.

Soviet legal material, like that in the U.S. and many other countries, may be divided into the basic categories of primary and secondary; official and unofficial; current and retrospective. Another basic division, reflecting the fact that the Soviet Union is a federal republic consisting of fifteen republics, is that between the all-union, or federal level of law, and the republic level. ${ }^{12}$

Primary legal material consists of the laws, rules, decisions, etc.,

"Stanislaw Pomorski, "The Language of the Soviet Constitution of 1977: A Note," Review of Socialist Law 7 (Sept. 198 I):331.

12 See Antonov, entire introduction, pp. 6-27, for an excellent, clear and concise account of the basic types of Soviet legal documents and publications. 
meant to guide human behavior which will be enforced by the state. Secondary material consists of all other publications dealing with law-textbooks, treatises, encyclopedias, journals, etc. They range from the most scholarly and authoritative to more basic, simpler material meant to explain aspects of law to the non-law student or layperson. In the Soviet Union, courses dealing with law or government are taught in secondary schools, and in higher educational institutions they are part of the curriculum for engineers, economists, technicians of every sort, medical personnel, agricultural workers, journalists, and so on. ${ }^{13}$ Many textbooks with basic titles and variations thereon such as "Soviet Law" or "Soviet State and Law" indicate on the title-page or verso of the title-page the intended audience. For instance, a I 982 book titled Soviet Law found in the Ginsburgs Collection is intended as a text for "students of higher educational institutions enrolled in the study of "economics of commerce." The chapters treat such areas of civil law as contract and obligations, credit relationships, and arbitration. There is a chapter devoted to criminal liability for commercial crimes. A book titled, in translation, Fundamentals of Soviet Law, is intended as a text for students in electrotechnical institutes of communications. An example of a popular book in the Ginsburgs Collection is entitled, in translation, Marriage, Family, Children: Talks on Family Legislation, and is intended for "parents and a wide circle of readers." The verso of the title page indicates that the book answers such questions as "what are the rights and obligations of parents in regard to their children? What responsibility does the parent have for actions of his children?"

Official publications are issued by government bodies and their official status is indicated by phrases such as "official text," or by an official seal. As in the U.S., it is the official version of an act which must be cited in legal documents. Current publications are issued chronologically, to make acts and decisions, etc., available as soon as possible, while retrospective publications enable a researcher to find out what acts or decisions existed in a certain area of law during a specific time-frame.

The most important official current legislative publication on the federal level is the weekly Gazette of the Supreme Soviet of the USSR

${ }_{13}$ William E. Butler, Soviet Law (London: Butterworths, 1983), p. 71. 
(Vedomosti Verkhounogo Soveta SSSR), which is available in the Ginsburgs Collection in hard copy from 1960, and on microfiche since 1954. The Supreme Soviet meets for only two sessions of about three or four days' duration per year. Between sessions, the Presidium, a smaller body selected from within the ranks of the Supreme Soviet, passes acts. Legislative acts fall into a hierarchical order. The highest form of act is the law [zakon] which may be passed only by the Supreme Soviet sitting as a body, and is always normative. The most important laws are the constitutional acts. Another important order of law consists of the Fundamentals [osnovy] which govern the codes of the republics. Next in importance are the edicts [ukaz] of the Presidium which may or may not be normative. The Presidium also issues a lower order of act, the decree, [postanovlenie] which is almost never normative. Most of the material in the Gazette consists of edicts. Acts must be published in the Gazette or the government newspaper Izvestiia within seven days of enactment. They become effective within ten days after publication, unless otherwise stipulated in the act itself.

Supreme Soviets and their Gazettes also exist on the republic level. The Ginsburgs Collection contains the Gazette of the Supreme Soviet of the RSFSR from 1963, and for the republic of Estonia since Sept. 1983. The latter has parallel texts in Russian and Estonian.

Another official publication of the Supreme Soviet of the USSR consists of the reports of its sessions [zadedanie] which include laws passed by it as well as other items on the agenda. However, this publication lacks the immediacy of the Gazette, as it comes out in hard cover quite a bit later than the seven-day time span of the Gazette. The Ginsburgs Collection contains the reports for several sessions.

While the Supreme Soviet is described in the Constitution as "the highest organ of state power" and as such is the highest legislative authority, non-Soviet commentators invariably point out that the Supreme Soviet is far from being a parliament in the western sense of the word because it lacks the autonomy of those institutions in the legislative area. The Communist Party, although it is nowhere given formal authority to initiate legislation, does in fact do so. Some western scholars have found that only two pieces of legislation were initiated by the Supreme Soviet in a recent IO-year 
period. ${ }^{14}$ Non-Soviet commentators explain that the Supreme Soviet, through its standing commissions, does perform important functions in examining draft legislation and proposing changes and amendments, as well as in examining the annual government plan and budget. ${ }^{15} \mathrm{O}$. S. Ioffe, the eminent emigré jurist who was mentioned earlier and who himself participated in the legislative process in the Soviet Union, stresses the "ceremonial" function of the Supreme Soviet, and states that no law is put before that body unless it has prior approval by the Communist Party. He writes that no instance of anything but a unanimous "yes" vote has ever been recorded in a law-passing session of the Supreme Soviet. ${ }^{16}$ The legislative activity of the Communist Party is carried out behind the scenes: "Formal initiative belongs to the agencies and people mentioned in the Soviet Constitution. Actual initiative, which is not mentioned anywhere, belongs to the Politbuto [of the Communist Party] . . . Those who have the right of formal initiative can not use it unless they are told to use their right by the bearer of actual initiative. And, conversely, the bearer of actual initiative prefers to use it not directly, but by the pre-determined activity of those with the right of formal initiative." 17

As in the United States, administrative law plays an important role in regulating society. The most important current official publication of administrative law is that put out by the highest executive body of the USSR, the Council of Ministers, which is called the government [pravitelstva] of the country. The publication is called Collection of the Ordinances of the Government of the USSR [Sobranie postanovlenii $i$ rasporiazhenii pravitelstva SSSR], which is now issued every ten to fourteen days. The regulations of the Council of Ministers are meant to carry out the legislation of the Supreme

${ }^{14}$ Stephen White, George Gardner, George Schöptlin, Communist Political Systems: An Introduction (New York: St. Martin's Press, I982), p. 86.

is Ibid, , pp. 85-88. Also very useful on the functions of the Supreme Soviet is Daniel Nelson and Stephen White, eds., Communist Legislatures in Comparative Perspective (Albany: State University of New York Press, 1982), pp. 140-143.

${ }^{16}$ O. S. Ioffe and Peter B. Maggs, Soviet Law in Theory and Practice (Dobbs Ferry, N.Y.: Oceana, I983), p. 106.

${ }_{17}$ Ibid., p. 99. Soviet commentators also point out the primary role of the Communist Party in the legislative process. See, for instance, B. M. Babii, ed., Sovershenstvovanie Sovetskogo zakonodatelstva na osnove Konstitutsii SSSR (The Carrying Out of Soviet Legislation on the Basis of the Constitution of the USSR) (Kiev: Naukova Dumka, I982), p. 15, p. 57. See also O. N. Sadikov, ed., Sovetskoe grazhdanskoe pravo (Soviet Civil Law) (Moscow: Iurid. lit-ra., 1983), p. Io. 
Soviet. Basically, the division is such that legislation addressed to the population at large, e.g. criminal law, constitutional law, etc., is enacted by the Presidium, while legislation addressed to specific individuals, groups, or organizations is passed by the Council of Ministers. Very important regulations are issued jointly by the Communist Party and the Council of Ministers, of the Presidium, the Council of Ministers, and the Communist Party.

Another current bulletin for normative acts of some ministries and commissions which are not included in the Collection is the Bulletin of Normative Acts of the Ministries and Administrative Agencies of the USSR [Biuleten normationykh aktov ministerstv $i$ vedomstv SSSR: Organ Ministerstva Iustitsii SSSR]. The Ginsburgs Collection's holdings for this item begin in I 973 .

While these regulations in the formal, explicit sense are substatutory and subordinate to law, in actuality the "substatutory" regulations often are more important than the laws [zakony] of the Supreme Soviet. O. S. Ioffe points out that this comes out clearly in the legal regulation of the economy. For instance, the statutory material on the contract of supply approved by the Supreme Soviet consists of only seven articles, while the two decrees on supply confirmed by the Council of Ministers in I98 I include 205 articles. ${ }^{18}$ This disproportion between statutory and administrative material in itself is not unusual in modern, bureaucratic states, Ioffe notes, but in the Soviet Union, unlike in the United States, for instance, where regulations are published in the Federal Register and the Code of Federal Regulations, regulations need not be published, leaving government free to adopt anything it wishes to be brought before interested parties confidentially. "And in cases when the Council of Ministries adopts a decision together with the Central Committee of the Communist Party, as a rule the necessary changes in the laws follow the decision, but do not precede them."19 One commentator states bluntly, in regard to the joint decisions of the Soviet government and the Communist Party, that it seems "unlikely that more than $50 \%$ of these joint decisions become known to the outside world." 20

${ }^{18}$ Ioffe and Maggs, p. 46.

${ }^{19}$ Ibid.

${ }^{20}$ Ger P. Van Den Berg, "Joint Party and Government Decrees and Guidance of the Direction of Soviet Agriculture," Review of Socialist Law IO (1984): 139. 
Although valuable for its currency, the speed with which it provides access to the newest acts, the chronological format of the bulletins and gazettes does not lend itself easily to research purposes, when subject access to legislation is sought. Compilations of laws, with their subject divisions, serve that purpose. The Ginsburgs Collection contains compilations dealing with a particular area of law, as well as those of a general nature. When using compilations, it is important to remember that laws are amended over time, and it is therefore necessary to note the date of the edition being used.

Commentators have decried the lack of a comprehensive, systematic arrangement of Soviet legislation, and have noted that the 1977 constitution made provisions for a "thorough, legislative house-cleaning." "2 One of the results of a commitment to systematize legislation is a multi-volume, loose-leaf digest, Digest of laws of the USSR (Svod zakonov SSSR), Moscow, I98 I- . This publication contains legislation, joint ordinances of the Council of Ministers of the USSR and the Central Committee of the Communist Party, and ordinances of a normative character. This digest is projected as a $\mathrm{I} 2$-volume set. The loose-leaf format will allow for regular updating as new material is sent out to subscribers. Although this digest, in its aim to be as comprehensive as possible, contains decrees which have not been published before, one western Sovietologist points out that the compilers of the new collection have instructions to omit regulations which must remain secret for security reasons. ${ }^{22}$ So far, the Ginsburgs Collection has received volume I, which deals with the structure of the state and society; volume 4 , which deals with the use and protection of natural resources, and volume 9, dealing with transport, communications, trade and housing. So far, the Ginsburgs Collection has also received volume I of the digests for the RSFSR and Latvian Republic, and volume 4 for the Estonian Republic.

Among important retrospective compilations in the Ginsburgs Collection is the 4-volume Collection of Laws of the USSR and Decrees of the Presidium of the Supreme Soviet of the USSR, I9381975, Moscow, I975-76. (The title is given in translation.) The Ginsburgs Collection also contain an earlier 3-volume set with the same title covering the years I938-I970.

\footnotetext{
${ }^{21}$ Ginsburgs and Pomorski, "A Profile," p. 55.

${ }^{22}$ Hazard, p. 48.
} 
An interesting early collection, published in 1920 in Moscow, is entitled, in translation, Systematic Compilation of the Most Important Decrees, I917-1920. It is divided into such chapters as: "State Structure"; "Division of the Church from the State"; "The Red Army"; "On Labor"; "On Enlightenment"; "Finance." (The chapter "On Enlightenment" includes the decree: "On the Centralization of Library Activity in the RSFSR, 3 Nov. I 920.")

In the foreword to this book, D. Kurskii, one of the prominent early Soviet jurists, writes that this volume contains the most important laws passed on the organization of the new state. He points out that the need for such a publication was brought out during the meeting of the Third International in Moscow in I9 I 9, when representatives from other countries wanted to have access to the most important acts of the Soviet government without having to read through the technical details on the management of the state at the same time.

Of great importance to the study of Soviet legislative history is the set Decrees of the Soviet Government (Dekrety sovetskogo pravitelstva), Moscow, I957- . This huge, multi-volume set gives the very first acts of the Soviet government in their official version. It also contains archival documents which are published for the first time in this compilation.

Among important retrospective republic collections of legislation is the I 5-volume compilation for the RSFSR, entitled, in translation, Systematic Collection of Laws of the RSFSR, Edicts of the Presidium of the Supreme Soviet of the RSFSR and Decisions of the Government of the RSFSR, Moscow, 1967-1970. Legislation for the Ukraine is found in the 2-volume Collection of Laws of the Ukrainian SSR and Edicts of the Presidium of the Supreme Soviet of the Ukrainian SSR, I938-1979, Kiev, I 980. Other republics which are represented in the Ginsburgs Collection with compilations of laws include Armenia, Georgia and the Kazakh SSR.

Besides this general type of compilation, there are also collections covering specific areas of law. Some examples of this type of material in the Ginsburgs Collection include the following items, whose titles are given in translation: Legislation on the Rights of Women: Collection of Normative Acts; Collection of Normative Acts on the Protection of Nature; Collection of Normative Acts on Industrial Legislation. 
Some collections of laws are meant as reference guides for officials in specific organizations, as, for instance, the annual Handbook for Trade-Union Officials (Spravochnik Profsoiuznogo rabotnika), which includes legislation and regulations pertaining to labor and employment matters.

Legal codes are very important because they provide the basic rules governing broad areas of law in a systematic, concise fashion. In the Soviet Union, there are only two all-union codes: the air code and the merchant shipping code. All other codes are promulgated by the republics themselves, based on the federal legislation called the "Fundamentals," which may be found in the Ginsburgs Collection. The Ginsburgs Collection is rich in its holdings of the codes of the various republics. In general, the codes correspond to the branches of law. Thus, there are civil codes, criminal codes, family codes, collective farm codes, etc. Since they all have to be based on the federal "Fundamentals," the codes of the various republics do not really differ very much from each other in the basic, substantive sense. However, regional differences do account for some interesting variations. One commentator has pointed out that while all the criminal codes consider the producing of alcoholic beverages at home a criminal offense, the Georgian republic permits the making of wine at home. ${ }^{23}$

Among the most authoritative texts in the Ginsburgs Collection are the commentaries to the codes, which are written and edited by well-known scholars. The format of the commentaries consists of the specific division of the code, followed by detailed explanations, interpretations and comments in regard to it.

Among the most important Communist Party materials in the Ginsburgs Collection are the stenographic records of the 2oth through the 26 th (most recent) Congresses. The record of the 2oth Congress is known to be incomplete, as it lacks Khrushchev's "Secret Speech" denouncing Stalin's crimes. This speech was never published in the Soviet Union, but the Ginsburgs Collection contains a version of it in English, as well as in Polish. Another important set of Party materials is entitled, in translation, The $C P S U$ in the Resolutions and Decisions of its Congresses, Conferences and Central Committee Plenums. This multi-volume serial compi-

${ }^{23}$ Harold J. Berman, "Codes and Codification," in Encyclopedia, v. I, p. I30. 
lation includes party documents and resolutions from I 898 to the present. Besides documentary Party material, the collection contains several hundred treatises dealing with all aspects of Party activity in the Soviet Union.

Two well-known Soviet scholars whose publications reflect extensive use of the Collection's Soviet legal as well as other sources, and whose works have been cited in this article, are George Ginsburgs and Stanislaw Pomorski, both of whom teach at the RutgersCamden Law School. Prof. Ginsburgs' works on Soviet law include the book, The Citizenship Law of the USSR (The Hague, I983), and the articles "Soviet Court Reform: I 956-1958"; "The New Soviet Citizenship Law and the Universal Declaration of Human Rights"; "The Reform of Soviet Military Justice: I 953-I 958"; "A Khrushchev Constitution for the Soviet Union: Projects and Prospects"; "Profile of the Soviet Constitution" (with Stanislaw Pomorski). He has been co-editor of the 3-volume series Soviet Law After Stalin, as well as of the compilation titled Soviet and East European Law and the Scientific-Technical Revolution.

Prof. Pomorski has written a book on American law titled American Criminal Law and the Principle of Nullum Crimen Sine Lege (Hague, I 975). His sphere of expertise in the Soviet area includes constitutional, criminal and economic law. His published articles concerning Soviet law include the following titles: "The Current Economic Law Debate and its Ramifications"; "Crimes against the Central Planner: 'Ochkovtiratelstvo' "; "Administration of Socialist Property in the USSR. New Trends and Institutions"; "The Scientific-Technical Revolution and Constitutional Developments"; "The Soviet Economic Associations: Some Problems of Legal Status and Organization after the I973 Reform"; and "Enforcement of Law and the Second Economy" (with George Ginsburgs).

As even this brief survey will have shown, much information concerning the Soviet system of law and government is available in the Ginsburgs Collection, and Winston Churchill's poetic phrase that "Russia is a riddle wrapped in a mystery inside an enigma" is much less true now than in I 939, when it was made. Sovietologists need the type of primary and secondary material which is contained in the Collection in order to perform their work of analyzing various aspects of the Communist system. This work has an explicitly prac- 
tical function in that it gives insight into a powerful nation that must be dealt with politically, and economically. But beyond the purely utilitarian purpose, the study of Soviet society is important for the same reason that the study of any society is worthwhile, whether it be that of the ancient Incas, the medieval Italian citystate or the Australian aborigine-because it increases an understanding of the human condition; and it is the desire to know, to analyze and to understand which distinguishes the human from that which is not. 